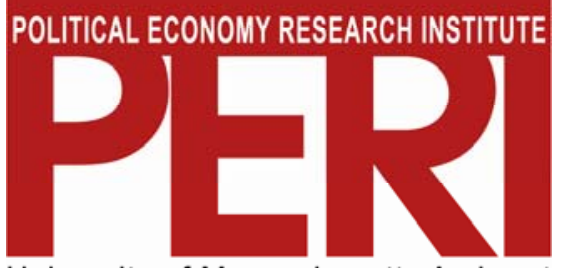

University of Massachusetts Amherst

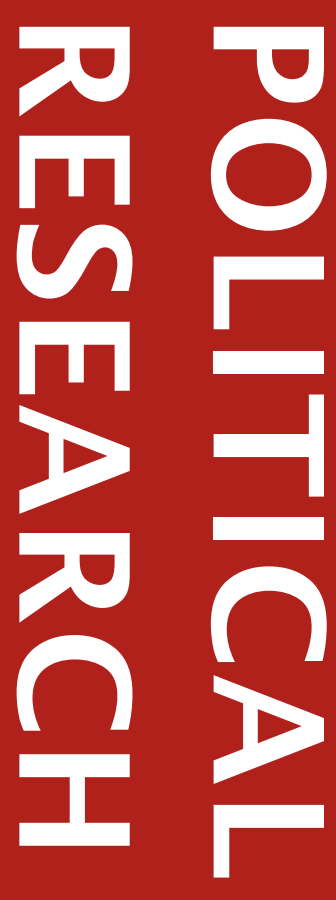

Did Retirees Save Enough to Compensate for the Increase in Individual Risk Exposure?

Christian E. Weller, Ph.D.

September 2009

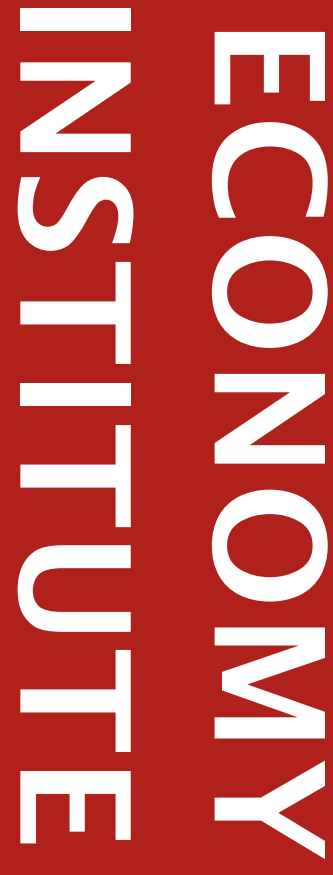

Gordon Hall

418 North Pleasant Street

Amherst, MA 01002

Phone: 413.545 .6355

Fax: 413.577 .0261

peri@econs.umass.edu

www.peri.umass.edu 


\title{
Did Retirees Save Enough to Compensate for the Increase in Individual Risk Exposure?
}

\author{
Christian E. Weller, Ph.D. \\ Associate Professor \\ Department of Public Policy and Public Affairs \\ University of Massachusetts Boston \\ McCormack Building 03-420 \\ 100 Morrissey Boulevard \\ Boston, MA 02125 \\ Christian.weller@umb.edu \\ (617) 287-6947 \\ and \\ Senior Fellow \\ Center for American Progress \\ Washington, DC
}

\begin{abstract}
The United States experienced an unprecedented financial crisis after 2007. This paper analyzes if retirees had enough wealth built up to weather the financial risks that materialized in the crisis. Financial risks associated with saving for retirement had increasingly shifted onto individuals away from the public and employers during the decades before the crisis. This growing personal responsibility should have gone along with more saving and less risk taking. I use data from the Federal Reserve's triennial Survey of Consumer Finances to first define an income threshold for retirees, specifically whether annuity income is greater than twice the poverty line - a common proxy for basic income needs. I then calculate the potential retirement income that retirees could expect if they translated all of their wealth into income and if the income is adjusted for market, idiosyncratic, and longevity risks. I compare the potential risk-adjusted income for retirees with annuity income above twice the poverty line to those retirees with annuity income below twice the poverty line. Both groups of retirees should have at least the same level of risk-adjusted potential retirement income. This comparison shows, however, that retirees with annuity income below twice the poverty line did not build up sufficient wealth to compensate for the rising financial risk exposure. Public policy thus should maintain existing sources of annuity income, promote greater annuitization of financial wealth, and encourage additional savings.
\end{abstract}

Key words: Retirement income adequacy; personal saving; financial risks 


\section{Introduction}

The crisis after 2007 created an unprecedented drop in personal wealth. Did retirees have enough of a financial cushion to withstand the fallout from the crisis without a drop in living standards? Individuals had to take more responsibility for saving for their retirement during the decades before the crisis and thus became increasingly exposed to the kind of financial market risks that materialized after 2007. On the other hand, the greater risk exposure was meant to give individuals an added incentive to save more for retirement. They therefore may have built up more of a financial cushion for a potential crisis than they otherwise would have. Household wealth after all increased relative to income during the decades before the crisis.

Most researchers, though, conclude that, despite sharp increases in wealth, a substantial share of families were still ill-prepared for retirement and that younger cohorts were increasingly less likely to be able to maintain their standard of living in retirement. This apparent contradiction between rising wealth and falling retirement income security may result from the fact that analyses of retirement income adequacy rely on measures of wealth that are not adjusted for the changing risk exposure of individuals over time.

My analysis thus researches if the shift towards more personal responsibility went along with sufficiently larger personal wealth to compensate for the concomitant increase in individual risk exposure. I consider the potential retirement income of two groups of retirees: those who receive annuities from pensions and Social Security that are at least twice as large as the poverty line and are thus have their basic living expenses covered and those who don't. I look at the potential income that both groups of retirees could expect to receive from all sources, including their wealth, after adjusting for the risks embedded in their wealth. If the shift towards more personal responsibility improved retirement income security, the risk adjusted potential retirement income 
of retirees with annuity income below twice the poverty line should be at least as large as the risk-adjusted potential retirement income of retirees with annuity income above twice the poverty line. If this is not the case, the shift towards more personal responsibility has gone along with a decline in retirement income security and requires policy attention to boost retirement income security after personal wealth has dropped dramatically.

My research adds to the existing literature in several ways. First, I explicitly account for individual risk exposure of retirees in calculating potential retirement income, instead of assuming many risks away. Second, I analyze the potential retirement income of current retirees instead of forecasting expected retirement income for future retirees, thus eliminating several sources of uncertainty about retirement income security. Third, I extend the research on retirement income adequacy to include data through 2007 to get a sense of how retirement income security changed just before the crisis occurred.

The rest of the paper is organized as follows. Section II discusses the relevant literature, followed by a presentation of some summary statistics in section III. In section IV, I present the concept of and data on risk-adjusted potential retirement income. Section V presents the multivariate regression analyses for retiree risk exposure, wealth, and income security, followed by concluding remarks and a discussion of the policy implications in section VI.

\section{Literature Review}

Retirement income adequacy is commonly defined as a minimum threshold - typically 75$80 \%$-- of the ratio of potential retirement income from Social Security, pensions, and private savings to pre-retirement income (Henle, 1972; Engen, Gale and Uccelo, 1999; RETIRE, 2001). The income needs of retirees are likely to be lower than those of workers since they no longer need to save for retirement, pay fewer taxes, have no work related expenses, have smaller 
families, and don't have a mortgage (Engen, Gale and Uccello, 1999). The target replacement rate, though, can vary with pre-retirement income levels and family status (CRR, 2006).

Most research finds that typically between $35 \%$ and $50 \%$ of U.S. workers cannot meet the replacement rate (Bernheim, 1997; Engen, Gale and Uccello, 1999; Gustman and Steinmeier, 1999; Moore and Mitchell, 2000; Munnell, Golub-Sass and Webb, 2007; Weller and Wolff, 2005). Expressed slightly differently, U.S. workers are saving only a fraction - a third or less of what they would need to save for adequate retirement income (Bernheim, 1997; Moore and Mitchell, 2000). These findings still hold, when only retirees are considered, instead of projecting future retirement income for current workers (Munnell and Soto, 2005;

An alternative approach to retirement income adequacy is the comparison of expected retirement income to an absolute standard, such as the poverty line or twice the poverty line (Butrica, Murphy and Zedlewski, 2007; Haveman et al., 2005; Love, Smith and McNair, 2008; Weller and Wolff, 2005). For instance, about 30\% of near-retiree families in 2001 were expected to fall short of having retirement income at least equal to twice the poverty line (Weller and Wolff, 2005), which can serve as a proxy for basic living standards (Russell, Bruce and Conahan, 2006).

Studies on retirement income adequacy typically eliminate substantial individual risk exposure in their calculations by assuming that retirees will purchase inflation adjusted annuities with their private wealth upon retirement.

Typically, though, retirees do not annuitize their savings (Perun, 2007), which means that the risk exposure of retirees has risen over time since the dependence on wealth that is automatically annuitized has declined. Fewer private sector workers, for instance, have defined benefit pensions and more have defined contribution plans (EBSA, 2008; BLS, 2008). 
This shift has increasingly exposed retirees to longevity, market, and idiosyncratic risks. Longevity risk could be reduced through lifetime annuities, but the vast majority of retirees do not annuitize their savings, even when given the chance (Perun, 2007). Moreover, savers can only reach a limited protection from market risks through diversification of their assets. And, savers may fall prey to idiosyncratic risks. Savers must make contribution, investment, and withdrawal choices by themselves in defined contribution plans, with a high chance of making the wrong choice (Benartzi and Thaler, 2007; Englehart, 1999; Hurd and Panis, 2006; Mitchell and Utkus, 2004; Munnell and Sunden, 2004).

There is theoretically a positive link between greater risk exposure and more saving. The rationale is that individuals save more to build a cushion against the possibility that the growing risks will materialize (Browning and Lusardi, 1996; Carroll and Samwick, 1998; Holst, 2005).

Researchers have similarly analyzed if the shift from defined benefit to defined contribution plans has resulted in more saving, but there is no clear conclusion in the literature. Papke (1999) concludes that defined contribution plans merely replace defined benefit plans without a net gain in personal retirement savings, Engen and Gale (2000) show that there are limited positive savings effects for low-income savers, and Benartzi and Thaler (2007) conclude that increases in tax incentives resulted in lower contribution rates since savers relied on heuristics rather than individual optimization. In comparison, Poterba et al. (2007) and Poterba, Venti, and Wise (2007) find a positive effect on personal saving, especially among higher-income earners.

The growing risk exposure should also have gone along with risk reduction strategies such as asset diversification and declining leverage in personal wealth. The data, though, indicate that the opposite has been the case. For instance, defined contribution plan participants do not optimally diversify across asset classes, often because choices are too complex (Benartzi and Thaler, 2007; 
Huberman and Jiang, 2006; Iyengar and Kamenica, 2006), they hold a relatively high share of their assets in their employer’s stock (Benartzi and Thaler, 2007; Holden et al., 2008; Fidelity Investments, 2008), and they only infrequently rebalance their portfolios (Mitchell, Mottola, and Utkus, 2005; Reid and Holden, 2008). Furthermore, leverage has generally increased among U.S. families (Weller and Sabatini, 2008).

Shifting the focus from all households to retirees, conclusions on the savings of retirees depend on the type of retirement plan they are covered by. Retirees with defined benefit plans tend to have more wealth than those with defined contribution plans (Copeland, 2007; Love, Smith and McNair, 2007). The risk exposure of retirees also seems to have increased with the shift from defined benefit to defined contribution plans (Copeland, 2006; Munnell and Sunden, 2004; VanDerhei et al., 2008; Weller, 2009). I will thus investigate if savings have increased enough, if at all, to compensate for the increasing risk exposure of retirees.

\section{Descriptive Statistics}

My sample comprises retirees 55 years of age and older from the Federal Reserves' triannual data Survey of Consumer Finances (SCF). The SCF includes comprehensive information on household wealth for every third year from 1989 to 2007.

I separate retirees into those who are exposed to more risks and those who are exposed to fewer risks. I use the level of annuity income from pensions and Social Security as an indicator for the level of risk exposure. Even though Social Security is expected to encounter financial shortfalls in the long run, proposals for Social Security reform typically exempt workers and retirees 55 and older from any changes. In a similar vein, although pension benefits could theoretically change due to an employer's bankruptcy, benefits are insured, within limits, by the Pension Benefit Guaranty Corporation (PBGC). It is thus reasonable to consider pension and 
Social Security incomes of current retirees as risk free. I then define a household as income secure if its annuity income is at least as large as twice the poverty line. Retirees with annuity income of at least twice the poverty line should have less wealth and possibly face more risks with their wealth than retirees with annuity income below twice the poverty line.

Table 1 summarizes trends on pension and Social Security income. Only 37.1\% of retirees had annuity income that was above twice the poverty line in 2007, down from 43.7\% in 2004. This decline after 2004 likely reflects broader economic trends and suggests that the deterioration in income security for retirees may have continued after 2007. The earlier increase before 2004 was likely a result of higher Social Security benefits that followed a strong labor market in the late 1990s and of solid pension benefits due to an extended stock market run (Weller and Wolff, 2005). The decline from 2004 to 2007 similarly may have gone along with fewer Social Security benefits due to an especially weak labor market, cuts to Social Security benefits for new retirees, starting in 2002, and a wave of pension freezes, following funding uncertainty due to large economic, financial market, and legal changes (Munnell et al., 2006).

Next, Table 1 compares wealth between retirees with annuity income above twice the poverty line and those without. I report total wealth relative to income to control for wealth differences that occur as a result of different income levels. ${ }^{1}$ There is no clear trend in differences of the wealth to income ratio by the level of annuity income.

The other side of income security is risk exposure, also shown in Table 1. I use the share of equities out of financial assets as indicator of financial asset diversification and debt levels as an indicator of leverage. There is again no systematic difference in equity shares and debt levels by annuity income levels.

\section{Income Replacement by Retirees}

\footnotetext{
${ }^{1}$ The differences are robust with averages, with all non-retirement wealth, and with non-housing wealth.
} 
My primary goal is to estimate the ability of retirees to maintain their standard of living even if financial risks materialize. I first calculate the risk-adjusted potential income that retirees could expect to generate from their wealth and then compare this potential retirement income to actual non-annuity income of retirees.

My calculation of risk-adjusted potential retirement income captures the spirit of previous retirement income adequacy studies since it accounts for all potential sources of retirement income, except earnings. ${ }^{2}$ The differences to previous research, though, are that I consider only retirees and thus do not have to forecast wealth to the time of retirement and that I explicitly account for the financial risk exposure in private assets instead of assuming it away. The result is a more accurate measure of retiree income security.

All marketable wealth is converted into potential risk-adjusted income. Marketable wealth is the sum of housing and non-housing wealth. I first determine the potential risk-adjusted income that retirees could receive from their owner-occupied housing. Potential income from living in an owner occupied home is typically encapsulated in the user costs of a homeowner, what an owner-occupied property would cost in the rental market. ${ }^{3}$ The basic calculation is defined by:

$$
\text { user } \cos t_{t}=P_{t}^{h}\left(i_{t}+\gamma-E \pi_{t}^{h}\right)
$$

where $P$ is the current price of the home, $i$ is the mortgage rate, $\gamma$ is the sum of depreciation, maintenance and repair, insurance, and property tax rates, which are all assumed to be constant and sum to $7 \%$, and $\pi$ is the one-year home price appreciation, and $E$ is an expectations operator. Data on house values are from the SCF, the mortgage rate is the average annual rate during the survey year (BOG, 2009b), and the expected home price appreciation is equal to the average

\footnotetext{
${ }^{2}$ My analysis sets earnings and personal saving to zero, which is common to retirement income adequacy studies.

${ }^{3}$ See Gardner and Verbrugge (2007) for a discussion of the relevant literature, the methodology, and the data.
} 
annual growth rate of the Home Price Index from the Office of Federal Housing Enterprise Oversight (OFHEO, 2009) during the preceding 15 years.

I also convert non-housing wealth -- non-housing assets minus non-mortgage debt - into potential income using a risk free real interest rate. This calculates the amount of annual income that retirees could expect from their wealth if the money were invested in risk free assets and increased with inflation each year. I use the 10-year average real interest rate for Treasury bonds with ten years of maturity for the calculation of the risk-free interest rate and subtract the 10-year average inflation rate based on the CPI-U-RS (BLS, 2009). Moreover, I assume that retirees will not annuitize their wealth and thus have to plan for their maximum life expectancy instead of the average life expectancy as would be the case if all wealth were annuitized. The maximum life expectancy is defined as 90 years for households younger than 90 years, 100 years for households between the ages of 90 and 99, and 105 years for households over the age of 100 . The use of a real risk free interest rates accounts for market and idiosyncratic risks, while the use of a maximum life expectancy instead of an average life expectancy accounts for longevity risk.

Total risk-adjusted potential income is the sum of annuity income, transfer income, real user costs of homes, and the real potential conversion value of non-housing wealth. ${ }^{4}$

Table 2 summarizes the data on risk-adjusted potential retiree income. It shows the total riskadjusted potential retiree income and it shows the non-annuity potential retiree income relative to discretionary income. I define discretionary as total income minus annuity income. The ratio of non-annuity potential income to discretionary income assumes that current income is equal to desired income. I thus define income security as maintaining the current level of consumption.

The data in Table 2 suggest that retirees with annuity incomes above twice the poverty line also enjoy greater overall income security than other retirees. The data show that retirees with

\footnotetext{
${ }^{4}$ I assume that annuities and transfer payments will grow with inflation.
} 
basic income security have higher risk-adjusted potential incomes than retirees without basic income security. This largely reflects the fact that retirees with basic income security tend to have more absolute wealth than retirees without basic income security. A substantial minority of retirees also were unable to maintain their current level of income, if they also wanted to protect themselves from market, idiosyncratic, and longevity risks. Thirty four percent of retirees with annuity incomes above twice the poverty line and $51.1 \%$ of retirees with less annuity income were unable in 2007 to replace their discretionary income with their potential risk-adjusted retirement income. Retirees with basic income security are better situated than their counterparts to maintain or even increase their current retirement income, although large shortfalls remain. ${ }^{5}$

The figures also indicate that there is substantial variability in the level of income security for retirees. The last peak of income security was typically 2001 for both groups of retirees. Retirement income adequacy thus had fallen even before the crisis occurred and likely left many retirees vulnerable to potential reductions in their retirement consumption.

\section{Multivariate analysis}

The descriptive statistics indicate that retirees with annuity income greater than twice the poverty level tend to be better positioned to maintain their standard of living throughout their retirement than other retirees. Much of this difference is likely explained by demographic differences and variation in savings attitudes. I consequently estimate multivariate regressions for retirement income security. The dependent variables are the natural logarithm of the total real potential income and the difference between risk-adjusted potential income and annuity income to discretionary income - the primary income replacement variable of interest in my research. The explanatory variables are demographic characteristics - race, family status, income, and age - and personal savings characteristics - willingness to take risks and homeownership.

\footnotetext{
${ }^{5}$ This conclusion also holds when total risk-adjusted potential income is related to permanent income.
} 
In addition, I include an indicator variable for basic income security in the regression analyses. It takes the value of "1" if annuity income from pensions and Social Security is at least twice as large as the poverty line and " 0 " otherwise. I alternatively use an indicator variable that takes the value of " 1 " if annuity income is at least as large as the poverty line to test for the robustness of my results and the continuous ratio of annuity income relative to total retiree income. These variables should have no or a negative systematic effect on the absolute or relative retirement income security if families compensate for greater financial risk exposure by saving more and investing in more secure assets. A positive coefficient, on the other hand, would imply that retirees did not fully compensate for increased financial risk exposure over the previous decades and thus likely experienced greater retirement income security during the period of financial and economic turmoil after 2007.

My sample includes retirees 55 years old and older and excludes households with potential income that is less than zero or greater than $\$ 2$ million as well as those with ratios of potential income minus annuity income relative to discretionary income that are greater than $700 \%$ to avoid that the results are influenced by outliers. My results are not sensitive to these restrictions.

Table 3 summarizes the estimates for the determinants of real risk-adjusted potential income. All coefficients have the expected signs or are statistically insignificant. My results show that retirement income security tends to be lower for minorities, single women, families with less educational attainment than their counterparts, households with lower risk tolerances, and renters.

The important explanatory variable in the regressions presented in Table 3 is the indicator variable for annuity income above twice the poverty line. This indicator variable is statistically significant and positively related to absolute and relative retirement income security. This 
indicates that retirees with annuity income above twice the poverty line are more likely than other retirees to maintain their overall standard of living throughout retirement, even if financial risks materialize. This implies that retiree self-insurance has not worked as expected.

Retirement income security may have deteriorated over time. Older retirees have more riskadjusted potential income than younger ones, which could signal that retirement income security may deteriorate in the future as retirees who can't rely as much on annuity income as previous cohorts enter retirement. Additionally, the estimates for the real values and for the replacement values of discretionary retiree income with annuity income at the poverty level as the threshold show that retirement income security in 2007 was below the levels of 2004 and 2001.

Are the differences in retirement income security for the two groups of retirees due to too little wealth, too much risk, or both? The next regressions test the relationship between wealth, risks, and annuity income. The wealth regression uses the ratio of total marketable wealth to income as the dependent variable. ${ }^{6}$ The explanatory variables are the same as before. The expectation is that the indicator variable for annuity income above twice the poverty line is negatively related with total wealth, suggesting that greater risk exposure leads to more wealth.

The regressions to test for risk reintroduce risks that had been eliminated in the calculations before in the calculation of risk-free potential retirement income, specifically longevity, market, and idiosyncratic risks. I eliminated longevity risk by assuming that assets will be drawn down over a maximum life expectancy. I now reintroduce longevity risk by assuming that retirees will draw down their financial wealth over their average life expectancy. I also eliminated market and idiosyncratic risks by discounting financial wealth by the risk-free real interest rate and assuming that retirees will live in their homes and not sell them. I now allow for market and idiosyncratic risk exposure by assuming that retirees will have to generate market rates of return on all of their

\footnotetext{
${ }^{6}$ The results are robust when I use non-housing wealth to income as the dependent variable.
} 
wealth. This implies that retirees are selling their homes to pay for their living expenses. The market rates of return for equities are the real total rate of return on the S\&P 500, the real interest rate on the 10-year treasury for non-equity financial wealth, and the real appreciation rate of owner-occupied housing based on OFHEO’s House Price Index, all averaged over 15 years.

The new risky dependent variables follow the model of the earlier dependent variable and are set relative to current discretionary income. The indicator variable for annuity income above twice the poverty line should have a negative relationship with the potential retirement income that allows for longevity or market risk exposure, just as before. Such a negative relationship would imply that retirees who have annuity incomes below twice the poverty line also have more private wealth, albeit with an increased financial risk exposure than other retirees.

An important additional aspect of my analysis is the change in the estimated parameter for the annuity income indicator. If the estimated difference shrinks after allowing for longevity risk, it would imply that retirees with annuity income below twice the poverty line are exposed to more longevity risk, largely because they are younger. A similar logic applies to the difference in market risk exposure. If retirees with annuity incomes below twice the poverty line are exposed to less market risk than other retirees, the reintroduction of market risks should widen the estimated gap in risk-exposed retirement income compared to risk-adjusted income. Allowing for greater risk exposure than before means that families will have to set aside less money to protect themselves from the chance that risks will materialize and thus have more retirement income available. This effect is greater for the group of families that faces more risks.

The first regression in Table 4 shows the estimates for total wealth to income. All variables have the expected signs or are statistically insignificant. The results show that retirees with annuity income below twice the poverty line have more wealth relative to income, as expected. 
This difference in wealth, though, is not enough to provide retirees who have annuity income below twice the poverty line with the same ability to maintain their standard of living as other retirees. The second and third regressions in Table 4 show that retirees with annuity income above twice the poverty line still enjoy greater retirement income security. The second regression, which allows for longevity risk exposure, shows that allowing for the annuitization of financial wealth shrinks the gap between the two groups of retirees. For the average retiree with annuity income above twice the poverty line the ratio of risk-adjusted potential retirement income minus annuity income to discretionary income is 37.2 percentage points greater than for other retirees. The difference shrinks to 21.1 percentage points when I allow for longevity risk exposure. Reducing the longevity risk exposure for retirees through annuitization of their financial wealth could thus substantially improve retirement income security.

The third regression shows the estimates after allowing for market and idiosyncratic risk exposure. Retirees with annuity incomes above twice the poverty line still enjoy more overall retirement income security than other retirees. The policy implication is thus that retirees with annuity income below twice the poverty line did not build up enough wealth to compensate for their remaining market risk exposure. Moreover, the difference in income security between these two groups widens when market risk is allowed, compared to the previous results, suggesting that retirees with annuity income above twice the poverty line are more exposed to market risks than other retirees, as the fifth regression in Table 4 confirms.

\section{Conclusion}

In this paper, I analyze income security for U.S. retirees before the crisis in 2008. Retirees were expected to become increasingly responsible for saving for retirement and manage the concomitant risks on their own. This increased financial risk exposure of individuals should 
contribute to higher wealth levels in order to compensate for the greater financial risks. Retirees who were able to rely less on traditional pensions and Social Security to cover their basic expenses indeed accumulated more wealth than those who could not, but not enough to generate the same level of retirement income secure and protection from financial market risks. Put differently, the basic income security of America's retirees was already declining before the crisis, as traditional pensions became less prevalent, Social Security benefits were gradually reduced, and financial risks associated with private savings remained high.

My results lead to three policy conclusions. First, public policy should help to reduce the risk exposure of retirees. My research indicates that greater annuitization of financial wealth can make a substantial difference in retirement income security by eliminating longevity risk. Third, policymakers should support efforts of families to save more in order to build more of a cushion for the eventuality that financial risks materialize as they did in 2007 and thereafter. My results indicate that retirees with lower annuities from Social Security and pensions did not compensate for this lack of income security by sufficiently saving to compensate for their market risk exposure. Second, policymakers should maintain and strengthen retirement savings vehicles that offer lifetime annuities to retirees, where feasible. My results show that so far retirees have not saved enough and sufficiently reduced financial risks to compensate for the greater individual risk exposure in private retirement savings.

The financial and economic crisis after 2007 exacerbated trends that had existed for decades because financial risks materialized after retirees had already become increasingly exposed to such risks. Policymakers should focus on improving the balance between personal responsibility and secured and guaranteed sources of retirement income. 


\section{Table 1}

Amounts and Income Shares of Annuitized Retiree Income, 1989 to 2007

\begin{tabular}{|c|c|c|c|c|c|c|c|}
\hline & 1989 & 1992 & 1995 & 1998 & 2001 & 2004 & 2007 \\
\hline $\begin{array}{l}\text { Median real annuitized income for } \\
\text { households with annuitized income }\end{array}$ & $\$ 18,626$ & $\$ 16,317$ & $\$ 18,001$ & $\$ 18,045$ & $\$ 18,034$ & $\$ 21,428$ & $\$ 20,594$ \\
\hline $\begin{array}{l}\text { Median share of annuitized income } \\
\text { out of total income for households } \\
\text { with annuitized income }\end{array}$ & 60.0 & 60.0 & 61.5 & 61.2 & 59.4 & 71.4 & 73.2 \\
\hline $\begin{array}{l}\text { Annuitized income exceeds twice } \\
\text { the poverty line, all households }\end{array}$ & 8.8 & 24.9 & 25.9 & 31.2 & 33.1 & 43.7 & 37.1 \\
\hline $\begin{array}{l}\text { Total wealth to income for } \\
\text { households with annuity income } \\
\text { above twice the poverty line }\end{array}$ & 408.0 & 518.3 & 535.6 & 423.9 & 500.7 & 578.7 & 558.7 \\
\hline $\begin{array}{l}\text { Total wealth to income for } \\
\text { households with annuity income } \\
\text { below twice the poverty line }\end{array}$ & 579.3 & 558.9 & 437.8 & 473.1 & 610.7 & 404.1 & 472.1 \\
\hline $\begin{array}{l}\text { Equities out of financial assets for } \\
\text { households with financial } \\
\text { investments and annuity income } \\
\text { above twice the poverty line }\end{array}$ & 28.1 & 22.3 & 26.8 & 42.3 & 53.3 & 48.3 & 33.8 \\
\hline $\begin{array}{l}\text { Equities out of financial assets for } \\
\text { households with financial } \\
\text { investments and with annuity } \\
\text { income below the poverty line }\end{array}$ & 26.7 & 28.6 & 41.2 & 42.0 & 52.0 & 41.7 & 42.9 \\
\hline $\begin{array}{l}\text { Median debt to income for retirees } \\
\text { with debt and with annuity income } \\
\text { above twice the poverty line }\end{array}$ & 28.8 & 31.0 & 21.4 & 46.5 & 43.9 & 41.5 & 46.6 \\
\hline $\begin{array}{l}\text { Median debt to income for retirees } \\
\text { with debt and with annuity income } \\
\text { below twice the poverty line }\end{array}$ & 27.4 & 22.0 & 33.2 & 44.8 & 32.4 & 59.9 & 77.6 \\
\hline
\end{tabular}

Notes: Due to the survey design, shares of income can theoretically be greater than $100 \%$, but are capped at $100 \%$. All financial variables reference the entire household. All figures are in percent, unless otherwise specified. 
Table 2

Summary Data on Retirement Income Security, 1989 to 2007

\begin{tabular}{|c|c|c|c|c|c|c|c|}
\hline & 1989 & 1992 & 1995 & 1998 & 2001 & 2004 & 2007 \\
\hline $\begin{array}{l}\text { Real risk-adjusted potential income } \\
\text { of retirees with annuity income } \\
\text { above twice the poverty line }\end{array}$ & $\$ 58,398$ & $\$ 61,032$ & $\$ 67,573$ & $\$ 63,459$ & $\$ 76,502$ & $\$ 76,215$ & $\$ 70,830$ \\
\hline $\begin{array}{l}\text { Real risk-adjusted potential income } \\
\text { of retirees with annuity incomes } \\
\text { below twice the poverty line }\end{array}$ & $\$ 32,553$ & $\$ 24,698$ & $\$ 25,981$ & $\$ 27,768$ & $\$ 28,227$ & $\$ 26,929$ & $\$ 30,249$ \\
\hline $\begin{array}{l}\text { Risk-adjusted potential income } \\
\text { minus annuity income relative to } \\
\text { discretionary income for retirees } \\
\text { with annuity income above twice } \\
\text { the poverty line }\end{array}$ & 102.0 & 122.6 & 129.8 & 132.3 & 136.3 & 131.4 & 118.2 \\
\hline $\begin{array}{l}\text { Risk-adjusted potential income } \\
\text { minus annuity income relative to } \\
\text { discretionary income for retirees } \\
\text { with annuity income below twice } \\
\text { the poverty line }\end{array}$ & 98.9 & 83.3 & 80.2 & 86.9 & 96.8 & 96.4 & 99.3 \\
\hline $\begin{array}{l}\text { Share of retirees with annuity } \\
\text { income above twice the poverty line } \\
\text { whose potential income minus } \\
\text { annuity income is smaller than their } \\
\text { discretionary income. }\end{array}$ & 48.7 & 33.2 & 30.8 & 30.7 & 27.7 & 30.0 & 34.5 \\
\hline $\begin{array}{l}\text { Share of retirees with annuity } \\
\text { income below twice the poverty line } \\
\text { whose potential income minus } \\
\text { annuity income is smaller than their } \\
\text { discretionary income. }\end{array}$ & 51.4 & 58.1 & 57.4 & 55.6 & 53.3 & 54.2 & 51.0 \\
\hline
\end{tabular}

Notes: All figures are in percent, unless otherwise noted. Absolute and relative risk-adjusted real amounts of potential income are medians. Shares of households are averages. 
Table 3

Regression Results for Determinants of Potential Income, 1989 to 2007

\begin{tabular}{|c|c|c|c|c|c|c|}
\hline \multirow[t]{2}{*}{ Variable } & \multicolumn{3}{|c|}{$\begin{array}{c}\text { Dependent variable: real potential income (natural } \\
\text { logarithm) }\end{array}$} & \multicolumn{3}{|c|}{$\begin{array}{l}\text { Dependent variable: potential income minus annuity } \\
\text { income to discretionary income }\end{array}$} \\
\hline & $\begin{array}{c}\text { Annuity } \\
\text { income above } \\
\text { twice the } \\
\text { poverty line }\end{array}$ & $\begin{array}{l}\text { Annuity } \\
\text { income above } \\
\text { the poverty line }\end{array}$ & $\begin{array}{c}\text { Annuity } \\
\text { income as share } \\
\text { of total income }\end{array}$ & $\begin{array}{c}\text { Annuity } \\
\text { income above } \\
\text { twice the } \\
\text { poverty line }\end{array}$ & $\begin{array}{c}\text { Annuity } \\
\text { income above } \\
\text { the poverty line }\end{array}$ & $\begin{array}{c}\text { Annuity } \\
\text { income as share } \\
\text { of total income }\end{array}$ \\
\hline Black & $\begin{array}{c}-0.304 * * * \\
(0.046)\end{array}$ & $\begin{array}{c}-0.230 * * * \\
(0.048)\end{array}$ & $\begin{array}{c}-0.352 * * * \\
(0.050)\end{array}$ & $\begin{array}{c}-0.228 * * * \\
(0.049)\end{array}$ & $\begin{array}{l}-0.181^{* * *} \\
(0.052)\end{array}$ & $\begin{array}{c}-0.304 * * * \\
(0.048)\end{array}$ \\
\hline Hispanic & $\begin{array}{c}-0.360 * * * \\
(0.101)\end{array}$ & $\begin{array}{c}-0.344 * * * \\
(0.097)\end{array}$ & $\begin{array}{c}-0.434 * * * \\
(0.103)\end{array}$ & $\begin{array}{c}-0.140 \\
(0.108)\end{array}$ & $\begin{array}{c}-0.131 \\
(0.108)\end{array}$ & $\begin{array}{c}-0.191 * \\
(0.105)\end{array}$ \\
\hline Other race & $\begin{array}{l}-0.233 \\
(3.317)\end{array}$ & $\begin{array}{l}-0.222 \\
(3.317)\end{array}$ & $\begin{array}{l}-0.274 \\
(3.317)\end{array}$ & $\begin{array}{l}-0.013 \\
(3.318)\end{array}$ & $\begin{array}{l}-0.007 \\
(3.318)\end{array}$ & $\begin{array}{l}-0.090 \\
(3.317)\end{array}$ \\
\hline Less than high school & $\begin{array}{l}-0.796 * * * \\
(0.039)\end{array}$ & $\begin{array}{c}-0.869 * * * \\
(0.038)\end{array}$ & $\begin{array}{c}-0.953 * * * \\
(0.041)\end{array}$ & $\begin{array}{l}-0.201 * * * \\
(0.064)\end{array}$ & $\begin{array}{c}-0.251^{* * *} \\
(0.061)\end{array}$ & $\begin{array}{c}-0.391^{* * *} \\
(0.060)\end{array}$ \\
\hline High school & $\begin{array}{c}-0.484 * * * \\
(0.033)\end{array}$ & $\begin{array}{c}-0.566 * * * \\
(0.033)\end{array}$ & $\begin{array}{c}-0.592 * * * \\
(0.035)\end{array}$ & $\begin{array}{c}-0.041 \\
(0.051)\end{array}$ & $\begin{array}{c}-0.097 * * \\
(0.048)\end{array}$ & $\begin{array}{c}-0.160 * * * \\
(0.046)\end{array}$ \\
\hline Some college & $\begin{array}{c}-0.260 * * * \\
(0.041)\end{array}$ & $\begin{array}{c}-0.320^{* * *} \\
(0.042)\end{array}$ & $\begin{array}{c}-0.314 * * * \\
(0.044)\end{array}$ & $\begin{array}{c}-0.006 \\
(0.068)\end{array}$ & $\begin{array}{c}-0.046 \\
(0.066)\end{array}$ & $\begin{array}{l}-0.083 \\
(0.063)\end{array}$ \\
\hline Single women & $\begin{array}{c}-0.149 * * * \\
(0.043)\end{array}$ & $\begin{array}{c}-0.193 * * * \\
(0.042)\end{array}$ & $\begin{array}{c}-0.249 * * * \\
(0.045)\end{array}$ & $\begin{array}{c}-0.169 * * \\
(0.078)\end{array}$ & $\begin{array}{c}-0.199 * * \\
(0.080)\end{array}$ & $\begin{array}{c}-0.210 * * * \\
(0.079)\end{array}$ \\
\hline Married & $\begin{array}{c}0.306^{* * *} \\
(0.044)\end{array}$ & $\begin{array}{c}0.333^{* * *} \\
(0.042)\end{array}$ & $\begin{array}{c}0.270 * * * \\
(0.045)\end{array}$ & $\begin{array}{c}-0.117 \\
(0.077)\end{array}$ & $\begin{array}{c}-0.100 \\
(0.079)\end{array}$ & $\begin{array}{c}-0.079 \\
(0.079)\end{array}$ \\
\hline Age & $\begin{array}{c}0.077 * * * \\
(0.030)\end{array}$ & $\begin{array}{l}0.061^{*} \\
(0.031)\end{array}$ & $\begin{array}{c}0.109 * * * \\
(0.032)\end{array}$ & $\begin{array}{c}-0.012 \\
(0.040)\end{array}$ & $\begin{array}{c}0.022 \\
(0.039)\end{array}$ & $\begin{array}{c}-0.073^{*} \\
(0.039)\end{array}$ \\
\hline Age $^{2}$ & $\begin{array}{c}-0.0004 * * \\
(0.0002)\end{array}$ & $\begin{array}{l}-0.0003 \\
(0.0002)\end{array}$ & $\begin{array}{c}-0.001 * * * \\
(0.0002)\end{array}$ & $\begin{array}{c}0.0003 \\
(0.0003)\end{array}$ & $\begin{array}{c}0.0002 \\
(0.0003)\end{array}$ & $\begin{array}{c}0.001^{* * *} \\
(0.0003)\end{array}$ \\
\hline Homeowner & $\begin{array}{c}0.657 * * * \\
(0.072)\end{array}$ & $\begin{array}{c}0.644^{* * *} \\
(0.070)\end{array}$ & $\begin{array}{c}0.680 * * * \\
(0.075)\end{array}$ & $\begin{array}{c}0.039 \\
(0.100)\end{array}$ & $\begin{array}{c}0.030 \\
(0.100)\end{array}$ & $\begin{array}{l}-0.055 \\
(0.099)\end{array}$ \\
\hline Risk attitude & $\begin{array}{c}-0.202^{* * *} \\
(0.021)\end{array}$ & $\begin{array}{c}-0.227 * * * \\
(0.022)\end{array}$ & $\begin{array}{c}-0.240 * * * \\
(0.023)\end{array}$ & $\begin{array}{c}-0.066^{* *} \\
(0.032)\end{array}$ & $\begin{array}{c}-0.083 * * * \\
(0.032)\end{array}$ & $\begin{array}{c}-0.150 * * * \\
(0.030)\end{array}$ \\
\hline $\begin{array}{l}\text { Has annuity income above twice the } \\
\text { poverty line }\end{array}$ & $\begin{array}{c}0.558 * * * \\
(0.025)\end{array}$ & & & $\begin{array}{l}0.372 * * * \\
(0.051)\end{array}$ & & \\
\hline Has annuity income above the poverty line & & $\begin{array}{l}0.510 * * * \\
(0.031)\end{array}$ & & & $\begin{array}{l}0.331^{* * *} \\
(0.032)\end{array}$ & \\
\hline Annuity income as share of total income & & & $\begin{array}{c}0.033 \\
(0.046)\end{array}$ & & & $\begin{array}{l}0.825^{* * * *} \\
(0.080)\end{array}$ \\
\hline
\end{tabular}




\begin{tabular}{|c|c|c|c|c|c|c|}
\hline 1992 & $\begin{array}{c}-0.273^{* * *} \\
(0.052)\end{array}$ & $\begin{array}{c}-0.372 * * * \\
(0.055)\end{array}$ & $\begin{array}{c}-0.183^{* * * *} \\
(0.053)\end{array}$ & $\begin{array}{c}-0.139 * * \\
(0.069)\end{array}$ & $\begin{array}{c}-0.202^{* * *} \\
(0.070)\end{array}$ & $\begin{array}{l}-0.073 \\
(0.067)\end{array}$ \\
\hline 1995 & $\begin{array}{c}-0.293^{* * *} \\
(0.056)\end{array}$ & $\begin{array}{c}-0.394 * * * \\
(0.057)\end{array}$ & $\begin{array}{c}-0.213^{* * *} \\
(0.056)\end{array}$ & $\begin{array}{c}-0.139 * * \\
(0.071)\end{array}$ & $\begin{array}{c}-0.204 * * * \\
(0.070)\end{array}$ & $\begin{array}{l}-0.096 \\
(0.066)\end{array}$ \\
\hline 1998 & $\begin{array}{c}-0.213^{* * *} \\
(0.051)\end{array}$ & $\begin{array}{c}-0.287 * * * \\
(0.055)\end{array}$ & $\begin{array}{c}-0.093^{*} \\
(0.053)\end{array}$ & $\begin{array}{l}-0.051 \\
(0.082)\end{array}$ & $\begin{array}{l}-0.098 \\
(0.080)\end{array}$ & $\begin{array}{c}0.031 \\
(0.074)\end{array}$ \\
\hline 2001 & $\begin{array}{c}-0.113^{* *} \\
(0.050)\end{array}$ & $\begin{array}{c}-0.219 * * * \\
(0.055)\end{array}$ & $\begin{array}{c}0.010 \\
(0.051)\end{array}$ & $\begin{array}{l}-0.052 \\
(0.077)\end{array}$ & $\begin{array}{l}-0.119 \\
(0.075)\end{array}$ & $\begin{array}{l}-0.004 \\
(0.070)\end{array}$ \\
\hline 2004 & $\begin{array}{c}-0.139 * * * \\
(0.050)\end{array}$ & $\begin{array}{c}-0.208 * * * \\
(0.053)\end{array}$ & $\begin{array}{c}0.038 \\
(0.051)\end{array}$ & $\begin{array}{l}-0.105 \\
(0.078)\end{array}$ & $\begin{array}{l}-0.146^{*} \\
(0.079)\end{array}$ & $\begin{array}{l}-0.056 \\
(0.076)\end{array}$ \\
\hline 2007 & $\begin{array}{c}-0.146^{* * *} \\
(0.055)\end{array}$ & $\begin{array}{c}-0.234 * * * \\
(0.059)\end{array}$ & $\begin{array}{l}-0.002 \\
(0.055)\end{array}$ & $\begin{array}{l}-0.107 \\
(0.070)\end{array}$ & $\begin{array}{c}-0.162^{* *} \\
(0.070)\end{array}$ & $\begin{array}{l}-0.068 \\
(0.066)\end{array}$ \\
\hline Constant & $\begin{array}{c}7.755^{* * *} \\
(1.129)\end{array}$ & $\begin{array}{c}4.921 * * * \\
(1.194)\end{array}$ & $\begin{array}{c}6.869 * * * \\
(1.201)\end{array}$ & $\begin{array}{c}0.598 \\
(1.414)\end{array}$ & $\begin{array}{c}1.051 \\
(1.371)\end{array}$ & $\begin{array}{c}3.049 * * \\
(1.378)\end{array}$ \\
\hline $\mathrm{N}$ & 3497 & 3497 & 3497 & 3497 & 3497 & 3497 \\
\hline Adjusted R-squared & 0.517 & 0.513 & 0.424 & 0.148 & 0.138 & 0.221 \\
\hline
\end{tabular}

Notes: All demographic variables refer to the head of household. Risk attitude measures a household's willingness to take financial risks on a four-point scale, where a lower number indicates a greater willingness to take financial risks. Regression results derive from a population-weighted regression. The results are robust for unweighted regressions. Missing reference variables are "white”, “college”, "single men”, "renter”, and “1989”. *** indicates significance at the 1\%level, ** indicates significance at the 5\%-level, and *** indicates significance at the $10 \%$-level. 
Table 4

Regression Estimates for Market Risk and Marketable Wealth for Retirees, 1989 to 2007

\begin{tabular}{|c|c|c|c|c|c|c|}
\hline Explanatory variables & $\begin{array}{l}\text { Wealth to } \\
\text { income }\end{array}$ & $\begin{array}{l}\text { Potential income } \\
\text { minus annuity } \\
\text { income to } \\
\text { discretionary } \\
\text { income, with } \\
\text { longevity risk } \\
\text { exposure }\end{array}$ & $\begin{array}{l}\text { Potential income } \\
\text { minus annuity } \\
\text { income to } \\
\text { discretionary } \\
\text { income, with } \\
\text { market risk } \\
\text { exposure }\end{array}$ & $\begin{array}{l}\text { Potential income } \\
\text { minus annuity } \\
\text { income to } \\
\text { discretionary } \\
\text { income, with } \\
\text { market and } \\
\text { longevity risk } \\
\text { exposure }\end{array}$ & $\begin{array}{l}\text { Equity out of } \\
\text { financial assets }\end{array}$ & $\begin{array}{c}\text { Houses out of } \\
\text { total assets }\end{array}$ \\
\hline $\begin{array}{l}\text { Real income (natural } \\
\text { logarithm) }\end{array}$ & - & - & - & - & $\begin{array}{c}0.108^{* * *} \\
(0.020)\end{array}$ & $\begin{array}{c}-0.124 * * * \\
(0.009)\end{array}$ \\
\hline Black & $\begin{array}{c}-2.215 * * * \\
(0.768)\end{array}$ & $\begin{array}{l}-0.056 * \\
(0.032)\end{array}$ & $\begin{array}{c}-0.275^{* * *} \\
(0.051)\end{array}$ & $\begin{array}{c}-0.117 * * * \\
(0.036)\end{array}$ & $\begin{array}{c}0.020 \\
(0.067)\end{array}$ & $\begin{array}{c}0.133^{* * *} \\
(0.030)\end{array}$ \\
\hline Hispanic & $\begin{array}{c}-3.122 * * * \\
(0.778)\end{array}$ & $\begin{array}{l}-0.017 \\
(0.065)\end{array}$ & $\begin{array}{l}-0.182 \\
(0.114)\end{array}$ & $\begin{array}{l}-0.070 \\
(0.072)\end{array}$ & $\begin{array}{l}-0.099 \\
(0.120)\end{array}$ & $\begin{array}{c}0.073 \\
(0.047)\end{array}$ \\
\hline Other race & $\begin{array}{l}-1.114 \\
(3.333)\end{array}$ & $\begin{array}{c}0.059 \\
(3.316)\end{array}$ & $\begin{array}{c}0.045 \\
(3.318)\end{array}$ & $\begin{array}{c}0.136 \\
(3.317)\end{array}$ & $\begin{array}{l}-0.180 \\
(3.317)\end{array}$ & $\begin{array}{c}0.029 \\
(3.316)\end{array}$ \\
\hline Less than high school & $\begin{array}{c}-4.266 * * * \\
(0.633)\end{array}$ & $\begin{array}{l}-0.008 \\
(0.032)\end{array}$ & $\begin{array}{c}-0.285^{* * *} \\
(0.069)\end{array}$ & $\begin{array}{c}-0.120 * * * \\
(0.040)\end{array}$ & $\begin{array}{c}-0.219 * * * \\
(0.041)\end{array}$ & $\begin{array}{c}0.090 * * * \\
(0.021)\end{array}$ \\
\hline High school & $\begin{array}{c}-2.707 * * * \\
(0.595)\end{array}$ & $\begin{array}{c}0.015 \\
(0.027)\end{array}$ & $\begin{array}{l}-0.106 * \\
(0.057)\end{array}$ & $\begin{array}{c}-0.071^{* *} \\
(0.036)\end{array}$ & $\begin{array}{c}-0.182 * * * \\
(0.031)\end{array}$ & $\begin{array}{c}0.041 * * \\
(0.017)\end{array}$ \\
\hline Some college & $\begin{array}{c}-1.825^{* *} \\
(0.683)\end{array}$ & $\begin{array}{c}0.030 \\
(0.033)\end{array}$ & $\begin{array}{l}-0.051 \\
(0.074)\end{array}$ & $\begin{array}{l}-0.035 \\
(0.043)\end{array}$ & $\begin{array}{c}-0.089 * * \\
(0.036)\end{array}$ & $\begin{array}{c}0.020 \\
(0.020)\end{array}$ \\
\hline Single women & $\begin{array}{l}-0.622 \\
(0.662)\end{array}$ & $\begin{array}{l}-0.069 * \\
(0.038)\end{array}$ & $\begin{array}{c}-0.188 * * \\
(0.082)\end{array}$ & $\begin{array}{c}-0.092 * * \\
(0.045)\end{array}$ & $\begin{array}{l}-0.029 \\
(0.048)\end{array}$ & $\begin{array}{c}0.021 \\
(0.027)\end{array}$ \\
\hline Married & $\begin{array}{l}-0.370 \\
(0.620)\end{array}$ & $\begin{array}{c}-0.126 * * * \\
(0.037)\end{array}$ & $\begin{array}{l}-0.109 \\
(0.082)\end{array}$ & $\begin{array}{c}-0.113^{* *} \\
(0.045)\end{array}$ & $\begin{array}{l}-0.003 \\
(0.044)\end{array}$ & $\begin{array}{c}0.078 * * * \\
(0.023)\end{array}$ \\
\hline Age & $\begin{array}{l}-0.309 \\
(0.336)\end{array}$ & $\begin{array}{c}0.094 * * * \\
(0.018)\end{array}$ & $\begin{array}{l}-0.006 \\
(0.043)\end{array}$ & $\begin{array}{c}0.109 * * * \\
(0.023)\end{array}$ & $\begin{array}{c}0.027 \\
(0.023)\end{array}$ & $\begin{array}{l}-0.019 \\
(0.014)\end{array}$ \\
\hline $\operatorname{Age}^{2}$ & $\begin{array}{l}-0.002 \\
(0.002)\end{array}$ & $\begin{array}{c}-0.001 * * * \\
(0.0001)\end{array}$ & $\begin{array}{c}0.0003 \\
(0.0003)\end{array}$ & $\begin{array}{c}-0.001 * * * \\
(0.0001)\end{array}$ & $\begin{array}{l}-0.0002 \\
(0.0002)\end{array}$ & $\begin{array}{c}0.0001 \\
(0.0001)\end{array}$ \\
\hline Risk attitude & $\begin{array}{c}-1.528 * * * \\
(0.342)\end{array}$ & $\begin{array}{c}0.009 \\
(0.016)\end{array}$ & $\begin{array}{c}-0.142 * * * \\
(0.036)\end{array}$ & $\begin{array}{c}-0.093 * * * \\
(0.023)\end{array}$ & $\begin{array}{c}-0.222 * * * \\
(0.020)\end{array}$ & $\begin{array}{c}0.060 * * * \\
(0.011)\end{array}$ \\
\hline Home ownership & & $\begin{array}{c}0.454^{* * *} \\
(0.045)\end{array}$ & $\begin{array}{l}-0.033 \\
(0.112)\end{array}$ & $\begin{array}{c}0.358 * * * \\
(0.066)\end{array}$ & & \\
\hline $\begin{array}{l}\text { Has annuity income } \\
\text { above twice the poverty }\end{array}$ & $\begin{array}{c}-3.191 * * * \\
(0.468)\end{array}$ & $\begin{array}{c}0.211 * * * \\
(0.025)\end{array}$ & $\begin{array}{c}0.403 \\
(0.057)\end{array}$ & $\begin{array}{c}0.254 * * * \\
(0.033)\end{array}$ & $\begin{array}{l}-0.036 \\
(0.027)\end{array}$ & $\begin{array}{c}0.031^{* *} \\
(0.014)\end{array}$ \\
\hline
\end{tabular}




\begin{tabular}{|c|c|c|c|c|c|c|}
\hline \multicolumn{7}{|l|}{ line } \\
\hline 1992 & $\begin{array}{c}1.348 \\
(0.675)\end{array}$ & $\begin{array}{c}-0.039 \\
(0.041)\end{array}$ & $\begin{array}{c}-0.137^{*} \\
(0.072)\end{array}$ & $\begin{array}{c}-0.038 \\
(0.045)\end{array}$ & $\begin{array}{c}0.072 \\
(0.053)\end{array}$ & $\begin{array}{c}0.040 \\
(0.026)\end{array}$ \\
\hline \multirow[t]{2}{*}{1995} & 0.619 & -0.059 & -0.105 & -0.015 & 0.091 & 0.011 \\
\hline & $(0.656)$ & $(0.040)$ & $(0.075)$ & $(0.047)$ & $(0.053)$ & $(0.026)$ \\
\hline \multirow[t]{2}{*}{1998} & $0.967^{*}$ & -0.062 & 0.053 & 0.068 & $0.132 * *$ & 0.011 \\
\hline & $(0.556)$ & $(0.043)$ & $(0.088)$ & $(0.053)$ & $(0.053)$ & $(0.045)$ \\
\hline \multirow[t]{2}{*}{2001} & $2.013 * * *$ & -0.039 & 0.031 & 0.075 & $0.172 * * *$ & $0.045^{*}$ \\
\hline & $(0.525)$ & $(0.041)$ & $(0.083)$ & $(0.051)$ & $(0.052)$ & $(0.027)$ \\
\hline \multirow[t]{2}{*}{2004} & $2.296 * * *$ & $-0.088^{* *}$ & -0.068 & -0.036 & $0.123 * *$ & $0.096 * * *$ \\
\hline & $(0.787)$ & $(0.039)$ & $(0.083)$ & $(0.046)$ & $(0.050)$ & $(0.027)$ \\
\hline \multirow[t]{2}{*}{2007} & $2.977 * * *$ & $-0.119 * * *$ & -0.068 & -0.064 & $0.157 * * *$ & $0.106 * * *$ \\
\hline & $(0.672)$ & $(0.037)$ & $(0.073)$ & $(0.041)$ & $(0.051)$ & $(0.026)$ \\
\hline \multirow[t]{2}{*}{ Constant } & 2.866 & $-3.149 * * *$ & 0.846 & $-3.109 * * *$ & -1.244 & $2.225^{* * *}$ \\
\hline & (12.217) & $(0.641)$ & (1.527) & $(0.850)$ & $(0.883)$ & $(0.509)$ \\
\hline $\mathrm{N}$ & 3497 & 3497 & 3497 & 3497 & 3497 & 3497 \\
\hline F-statistics & $103.16^{* * *}$ & & & & & \\
\hline Adjusted R-squared & 0.095 & 0.104 & 0.137 & 0.099 & 0.182 & 0.349 \\
\hline
\end{tabular}

Notes: Risk regressions are censored regressions. All demographic variables refer to the head of household. Risk attitude measures a household's willingness to take financial risks on a four-point scale, where a lower number indicates a greater willingness to take financial risks. Regression results derive from a population-weighted regression. The results are robust for unweighted regressions. Missing reference variables are "white”, "college”, "single men”, "renter", and "1989". *** indicates significance at the $1 \%$-level, ** indicates significance at the 5\%-level, and *** indicates significance at the $10 \%$-level. 


\section{References}

Benartzi, S. and R. Thaler, 2007, Heuristics and Biases in Retirement Savings Behavior, Journal of Economic Perspectives Vol. 21 No. 3: 81-104.

Bernheim, D.B., 1997, The Adequacy of Personal Retirement Saving: Issues and Options, in Wise, David A., ed., Facing the Age Wave, Stanford CA: Hoover Institute Press.

Board of Governors, Federal Reserve System, 2009a, Survey of Consumer Finances, various years, Washington, DC: BOG.

Board of Governors, Federal Reserve System, 2009b, Release H.15: Selected Interest Rates, Washington, DC: BOG.

Browning, M., and Lusardi, A., 1996, Household saving: Micro Theories and Macro Facts, Journal of Economic Literature, 34: 1797-1855

Bureau of Labor Statistics, 2009, Updated CPI-U-RS, All Items and All items less food and energy, 1978-2008, Washington, DC: BLS.

Bureau of Labor Statistics, 2008, National Compensation Survey, Washington, DC: BLS.

Butrica, B., Murphy, D., and Zedlewski, S.R., 2007, How Many Struggle to Get By in Retirement?, CRR Working Paper No. 2007-27, Boston, MA: Center for Retirement Research at Boston College.

Center for Retirement Research, 2006, Retirements at Risk: A New National Retirement Risk Index, Boston, MA: CRR at Boston College.

Carroll, C. and Samwick, A., 1998, How Important is Precautionary Saving? Review of Economics and Statistics, 80, 410-419.

Copeland, C., 2006, Debt of the Elderly and Near Elderly, 1992-2004, EBRI Notes 27 (9): 2-13, Washington, DC: Employee Benefit Research Institute. 
Copeland, C., 2007, How Are New Retirees Doing Financially in Retirement? EBRI Issue Brief No. 302. Washington DC: Employee Benefit Research Institute.

Employee Benefit Security Administration, 2008, Private Pension Bulletin 2006, Abstract Form 5500, Washington, DC: EBSA.

Engen, E. M. and Gale, W. G. 2000, The Effects of 401(k) Plans on Household Wealth:

Differences Across Earnings Groups, Washington: The Brookings Institution.

Engen, E.M., Gale, W.G., and Uccello, C.E., 1999, The Adequacy of Household Saving, Brookings Papers on Economic Activity 2:65-165.

Englehart, G., 1999, Have 401(k)s Raised Household Saving? Evidence from the Health and Retirement Study, Aging Studies Program Working Paper No. 14. Syracuse, NY: Syracuse University.

Fidelity Investments, 2009, Fidelity Reports on 2008 Trends in 401(k) Plans,” Boston.

Garner, T.I., and Verbrugge, R., 2007, The Puzzling Divergence of U.S. Rents and User Costs, 1980-2004: Summary and Extensions, BLS Working Paper No. 409, Washington, DC:

Bureau of Labor Statistics.

Gustman, A., and Steinmeier, T. L. 1999, Effects of Pensions on Savings: Analysis With Data From the Health and Retirement Study, Carnegie-Rochester Conference Series on Public Policy 50, No. 99: 271-324

Haveman, R., Holden, K., Wolfe, B., and Romanov, A., 2005, Assessing the Maintenance of Savings Sufficiency over the First Decade of Retirement, CESIfo Working Paper No. 1567, Munich, Germany: CESIfo.

Henle, P., 1972, Recent Trends in Retirement Benefits Related to Earnings, Monthly Labor Review 95, No.6: 12-20. 
Holden, S., VanDerhei, J., Alonso, L, and Copeland, C., 2008, 401(k) Plan Asset Allocation, Account Balances, and Loan Activity in 2007, Research Perspective Vol. 14, No. 3 Washington: Investment Company Institute

Holst, R., 2005, Wealth Accumulation with Risky Social Security: Empirical Evidence from US Micro and Macro Data, unpublished manuscript, Chicago, IL: University of Chicago.

Huberman, G. and Jiang, W., 2006, Offering versus Choice in 401(K) Plans: Equity Exposure and Number of Funds, Journal of Finance 61.2, 763 - 801

Hurd, M. and Panis, C., 2006, The Choice to Cash Out Pension Rights at Job Change or Retirement, Journal of Public Economics Vol. 90, No. 12: 2213-2227.

Iyengar, S., and Kamenica, E., 2006, Choice Overload and Simplicity Seeking, Working paper, Columbia University.

Love, D., Smith, P., and McNair, L., 2008, A New Look at the Wealth Adequacy of Older U.S. Households, Review of Income and Wealth. 54 (4): 616-642.

Love, D., Smith, P. and McNair, L., 2007, Do Households Have Enough Wealth for Retirement? Finance and Economics Discussion Series No. 2007-17. Washington, DC: Board of Governors, Federal Reserve System.

Mitchell, O., Mottola, G.R., and Utkus, S., 2005, The Inattentive Participant: Portfolio Trading Behavior in 401(k) Behavior, Pension Research Council Working Paper 2006-5, Philadelphia, PA: Pension Research Council, Wharton School, University of Pennsylvania. Mitchell, O. and Utkus, S., 2004, Pension Design and Structure: New Lessons from Behavioral Finance, New York, NY: Oxford University Press. 
Moore, J. F., and Mitchell, O. S., 2000, Projected Retirement Wealth and Saving Adequacy, in Mitchell, O., Hammond, B., and Rappaport, A., eds., Forecasting Retirement Needs and Retirement Wealth, Philadelphia PA: University of Pennsylvania Press.

Munnell, A., Golub-Sass, F. and Webb, A., 2007, What Moves the National Retirement Risk Index? A Look Back and an Update, CRR An Issue in Brief No. 7-1, Boston, MA: Center for Retirement Research at Boston College.

Munnell, A., Golub-Sass, F., Soto, M. and Vitagliano, F., 2006, Why Are Healthy Employers Freezing their Pension Plans?, CRR An Issue in Brief No. 44, Boston, MA: Center for Retirement Research at Boston College.

Munnell, A., and Soto, M., 2005, How Do Pensions Affect Replacement Rates?, CRR An Issue in Brief No. 37, Boston, MA: Center for Retirement Research at Boston College.

Munnell, A. and Sunden, A., 2004, Coming Up Short: The Challenge of 401(k) Plans, Washington, DC: Brookings Institution Press.

Office of Federal Housing Enterprise Oversight, 2009, Home Price Index, Washington, DC: OFHEO.

Papke, L., 1999, Are 401(k) Plans Replacing Other Employer-Provided Pensions? Evidence from Panel Data, Journal of Human Resources 34, No. 2:346-68.

Perun, P., 2007,Putting Annuities Back into Savings Plans, In T. Ghilarducci and C. Weller, eds. Employee Pensions: Policies, Problems, and Possibilities. Champaign IL: Labor and Employment Relations Association.

Poterba, J., Rauh, J., Venti, S., and Wise, A., 2007, Defined Contribution Plans, Defined Benefit Plans, and the Accumulation of Retirement Wealth, Journal of Public Economics 91, No. 10: 2062-86. 
Poterba, J., Venti, S., and Wise, A., 2007, The Changing Landscape of Pensions in the United States, NBER Working Paper No. 13381, Cambridge, MA: National Bureau of Economic Research.

Reid, B. and Holden, S., 2008, Retirement Saving in Wake of Financial Market Volatility, Washington: Investment Company Institute.

RETIRE Project, 2001, 2001 RETIRE Project Report, Atlanta GA: Georgia State University. Russell, L.H., Bruce, E.A., and Conahan, J., 2006, A Methodology to Determine Economic Security for Elders, Boston, MA: Gerontology Institute, University of Massachusetts Boston, and Washington, DC: Wider Opportunities for Women.

VanDerhei, J., Holden, S., Alonso, L., and Copeland, C., 2008, 401(k) Plan Asset Allocation, Account Balances, and Loan Activity in 2007, EBRI Issue Brief No. 324, Washington, DC: Employee Benefit Research Institute.

Weller, C., 2009, Risk Matters: Retirees Exposed to Growing Risks, paper presented at the “Financial Institutions and Economic Security” conference of the Innovation Knowledge Development network and The Open University, London, UK, May 21, 2009.

Weller, C., and Sabatini, K., 2008, From Boom to Bust: Did the Financial Fragility of Homeowners Increase in an Era of Greater Financial Deregulation?, Journal of Economic Issues 42, No.3: 607-632.

Weller, C., and Wolff, E., 2005, Retirement Security: The Particular Role of Social Security, Washington, DC: Economic Policy Institute. 